\title{
PENGARUH PEMBERIAN KIRINYU(Chromolaena odorata) SEBAGAI SUMBER BAHAN ORGANIK TERHADAP PERTUMBUHAN DAN HASIL DUA VARIETAS CABAI BESAR (Capsicum annum)
}

\author{
Kristono Yohanes Fowo, Murdaningsih, Willybrodus Lanamana \\ Jurusan Agroteknologi Fakultas Pertanian Universitas Flores
}

\begin{abstract}
ABSTRAK
This studyaims to determine the effect of giving Kirinyu (Chromolaena odorata) as a source of organic matter on growth and yield of two varieties of Chilli (Capsicum annum), and to determine the optimum dose Kirinyu that can improvecrop growth and yield of the Big Chilli, research was conducted in the Garden University College of Agriculture experiment Flores, Village Lokoboko, District Ndona, Ende with \pm 500 meter saltitudeabove sea level, starting in September 2010-April 2011.

The designusedin this studyis the Group Randomized Factorial Design with the treatment, the first factor $(\mathrm{V})$ is the treatment of varieties consisting of Variety HotBeauty (V1), and Varieties Amando (V2), and the second factor (K) is the dose of organic material Kirinyu namely K0 (without Kirinyu), K1 (Kirinyu10 tons/ha), K2 (Kirinyu15 tons/ha), K3 (Kirinyu20 tonnes/ha). Variable observations in this study was "Higher Plants, Number of Leaves, Leaf Area, Total Fruit, Fruit diameter and weight of fruitper plant".

The results showed that administration of doses as a source of organic material Kirinyu significant effect on the varieties (V) and different doses Kirinyu to Total Leaf, Leaf Area observations at age 42 days after transplanting (DAT), and also significantly influenced Number of Fruit, Fruit Weight, and fruit diameter. Use of Hot Beauty varieties has increased to Total Leaf (21.67 strands), number of fruits (31.00 fruits), and fruit weight (279.00 grams) and more resistant to high rainfall intensity, and for variety Amando has increased to broad leaves $(187.02 \mathrm{~cm})$, and fruit diameter $(1.74 \mathrm{~cm})$ and not resistant to rain intensity. But for Kirinyu dose also significantly influenced leaf number, leaf area at the age of 42 observation days after transplanting (DAT), and also significantly influenced fruit number, fruit weight and fruit diameter. Chili optimum plant growth shown in the use Kirinyu a dose of 20 tonnes / ha ie number of leaves (19.23 strands), leaf area $(208.25 \mathrm{~cm})$, number of fruits (41.58), fruit weight $(7.44$ grams $)$, fruit diameter $(1.66 \mathrm{~cm})$.
\end{abstract}

Kata kunci: Kirinyu, Dosis Bahan Organik, Varietas Cabai.

\section{PENDAHULUAN}

Cabai Merah (Capsicum annum) merupakan salah satu komoditas sayuran yang tidak dapat ditinggalkan masyarakat dalam kehidupan sehari - hari serta sangat prospektif dan mempunyai nilai ekonomis, dimana Cabai juga mempunyai kegunaan sangat beragam, seperti sebagai bumbu dapur, bahan baku industri makanan, obat-obatan, zat pewarna, dan bahan campur minuman. Cabai juga 
mengandung nilai gizi diantaranya Kalori, Protein, Lemak, Karbohidrat, Kalsium, Vitamin A, B1 dan Vitamin C (Prajnata, 1995).

Tanaman Cabai termasuk jenis sayuran buah dengan rasa spesifik, yaitu pedas. Rasa pedas pada Cabai disebabkan oleh adanya kandungan Capsaicin. Capsaicin terdapat pada biji cabai dan plasenta, yaitu kulit Cabai bagian dalam yang berwarna putih tempat melekatnya biji, selain mengandung Capsaicin Cabai juga mengandung semacam minyak Adsiri yaitu Capsicol sebagai pengganti minyak kayu putih dan bermanfaat bagi kesehatan manusia (Setiadi, 1995).

Potensi lahan yang sesuai dengan persyaratan tumbuh tanaman Cabai di NTT yaitu 560 ha, sedangkan luas areal panen 411 ha, dengan ratarata produksi 27,24 ton (Anonimus, 2007). Sedangkan luas areal yang dapat di tanami tanaman Cabai untuk di Kabupaten Ende yaitu 11,20 ha, sementara lahan yang dapat dipanen seluas 9,50 ha, sehingga ada 1,7 ha lahan yang tidak dapat dipanen karena teknik bididaya yang kurang baik diantaranya kurangnya perawaratan, pemilihan varietas yang tidak sesuai, serta teknik pemupukan yang hanya semata-mata menggunakan pupuk anorganik yang memiliki pengaruh negatif terhadap tingkat kesuburan tanah (Dinas Pertanian Kabupaten Ende, 2010).

Tanaman Cabai Besar terdiri dari beberapa varietas diantaranya varietas Hot Beuaty dan varietas Amando. Varietas Cabai Besar jenis ini sudah banyak dikenal oleh masyarakat petani khususnya masyarakat petani di Kabupaten Ende, varietas ini merupakan varietas Cabai Besar yang paling banyak dibudidayakan oleh petani, karena memiliki kelebihan diantaranya ukuran buahnya yang besar, panjang dan lurus, pertumbuhan tanaman Cabai ini subur, pembentukan buah terus menerus sehingga masa panen lebih lama.

Salah satu perlakuan yang baik untuk meningkatkan hasil Cabai ialah dengan melakukan pemupukan diantaranya pupuk anorganik dan pupuk organik. Bagi petani di Kabupaten Ende, penggunaan pupuk anorganik sudah tidak asing lagi bagi para petani, karena pupuk anorganik sudah sering digunakan oleh petani di Ende. Namun, praktek pemupukan dengan menggunakan bahan organik masih relative terbatas penggunaan oleh para petani. Bahan organik seperti Kompos dan Pupuk Hijau dapat memberikan keuntungan di berbagai bidang. Bahan organik dapat juga disebut pupuk lengkap karena bahan organik dapat menyediakan semua unsur hara baik makro maupun mikro. Pemberian bahan organik pada tanah sebagai tempat tumbuh tanaman juga berperan penting dalam meningkatkan produktifitas tanah dan tanaman, serta dapat memperbaiki sifat fisik, kimia, maupun biologi tanah yang sesuai bagi pertumbuhan tanaman serta lebih menguntungkan karena lebih ramah lingkungan serta kualitas hasil yang tidak memberikan dampak yang merugikan bagi kesehatan makluk hidup yang memenfaatkannya dalam kehidupan sehari-hari (Karieeen, 2007).

Pemberian bahan organik terhadap tanaman Cabai merupakan sala satu cara yang digunakan dalam peningkatan produksi dengan tujuan untuk meningkatkan ketersediaan unsur hara bagi tanaman. Di lapangan, pilihan pemberian bahan organik dengan tujuan pemupukan tanaman budidaya dapat dilakukan dengan menggunakan biomasa Kirinyu (Chromolaena odorata). Di Ende Kirinyu tidak asing dan tidak jarang ditemukan serta keberadaanya hanya sebagai gulma dan 
sangat berlimpah, sehingga secara mudah dan murah dapat diambil dengan tujuan untuk dugunakan sebagai sumber bahan organik. Biomasa Kirinyu sangat baik dalam peningkatan kandungan bahan organik karena mengandung unsur Nitrogen yang cukup tinggi disamping unsur hara Fosfor dan Kalium.

Penelitian ini bertujuan untuk mengetahui pengaruh interaksi pemberian Kirinyu dan varietas Cabai Besar terhadap pertumbuhan dan hasil, untuk mengetahui dosis optimum Kirinyu yang dapat meningkatkan hasil Cabai Besar, dan untuk mengetahui respon pertumbuhan dan hasil akibat perlakuan dosis Kirinyu.

Dilihat dari hal di atas yaitu makin mahalnya pupuk buatan, dan dampak negatif yang yang ditimbulkan dalam waktu yang lama oleh pupuk buatan terhadap lingkungan serta kualitas hasil, maka perlu dilakukan pemupukan organik dalam kegiatan budidaya tanaman. Salah satu upaya untuk meningkatkan efisiensi penggunaan pupuk adalah dengan pemberian bahan organik dari Kirinyu, karena Kirinyu dapat menyumbangkan unsur hara N,P,K, bagi tanaman budidaya dan memperbaiki sifat fisik, biologi, dan kimia. Bahan organik merupakan bahan penting dalam memperbaiki sifat-sifat tanah (Hakim, Yusuf, Lubis, Bailay, 1986).

Melihat tingginya kandungan unsur hara pada jaringan Kirinyu dan tingkat pelapukan yang relatif cepat (24 bulan), maka diduga Kirinyu dapat dijadikan sebagai sumber bahan organik pada tanaman Cabai varietas Hot Beauty dan varietas Amando, dengan asumsi bahwa varietas tersebut telah dapat memenfaatkan hasil dekomposisi bahan organik pada usia 60 hari setelah tanam. Terbatasnya informasi pemberian Kirinyu sebagai sumber bahan organik pada pertumbuhan dan hasil tanaman Cabai maka perlu dilakukan penelitian ini.

\section{BAHAN DAN METODE}

Penelitian ini dilakukan di Kebun Percobaan Fakultas Pertanian Universitas Flores yang berada di Kelurahan Lokoboko, Kecamatan Ndona, Kabupaten Ende. Berdasarkan hasil penelitian terdahulu ketinggian tempat $500 \mathrm{~m}$ dpl, suhu rata- rata $27,45^{\circ} \mathrm{C}-31^{\circ} \mathrm{C}$, jenis tanah lempung berpasir. Penelitian ini dilakukan mulai bulan September 2010 sampai dengan bulan April 2011.

Bahan yang digunakan adalah tanaman Kirinyu (Chromolaena odorata), sebagai sumber bahan organik, benih cabai yaitu varietas "Hot Beauty dan Amando"Alat-alat yang digunakan dalam percobaan ini meliputi: parang, cangkul, sabit, ajir, tugal atau tofa, penggaris dan meteran untuk mengukur tinggi tanaman pada percobaan lapangan, mistar untuk mengukur lebar daun, timbangan jangka sorong, alat tulis menulis.

\section{Rancangan Penelitian.}

Percobaan disusun berdasarkan Rancangan Acak Kelompok secara Faktorial, yang diulang sebanyak 3 kali. Faktor pertama adalah varietas tanaman Cabai dengan 2 level yaitu: V1: Varietas Hot Beauty. V2: Varietas Amando. Faktor kedua yaitu dosis Kirinyu dengan 4 level):KO= Kontrol, $\mathrm{K} 1=10$ ton/ ha, $\mathrm{K} 2=15$ ton/ ha, $\mathrm{K} 3=20$ ton/ ha. Sehingga diperoleh 8 kombinasi perlakuan yaitu:V1K0: Varietas Cabai Hot Beauty, tanpa pemberian Bahan Organik dari Kirinyu (Chromolaena odorata). V1K1:

Varietas Cabai Hot Beauty + Penambahan Bahan Organik dari Kirinyu (Chromolaena odorata) 10 ton/ha $(1 \mathrm{~kg} / \mathrm{m} 2) . V 1 \mathrm{~K} 2: \quad$ Varietas Cabai Hot Beauty + penambahan Bahan 
Organik Kirinyu 15 ton/ha (1,5 $\mathrm{kg} / \mathrm{m} 2) . V 1 \mathrm{~K} 3$ : Varietas Cabai Hot Beauty + penambahan Bahan Organik Kirinyu 20 ton/ha $(2 \mathrm{~kg} / \mathrm{m} 2)$.V2K0: Varietas Cabai Amando, tanpa pemberian Bahan Organik Kirinyu. V2K1:Varietas Cabai Amando + Penambahan Bahan Organik Kirinyu 10 ton/ha $(1 \mathrm{~kg} / \mathrm{m} 2) . \mathrm{V} 2 \mathrm{~K} 2$ :Varietas Cabai Amando + penambahan Bahan Organik Kirinyu 15 ton/ha $(1,5 \mathrm{~kg} / \mathrm{m} 2)$.V2K3: Varietas Cabai Amando + Penambahan Bahan Organik Kirinyu 20 ton $/ \mathrm{ha}(2 \mathrm{~kg} / \mathrm{m} 2)$.

\section{Pelaksanaan Penelitian}

Variabel yang diamati pada percobaan ini meliputi: Tinggi Tanaman (cm)diukurdengan meteran mulai di atas permukaan tanah sampai pada titik tumbuh. Pengamatan tinggi tanaman berakhir pada saat peralihan masa vegetatif ke generatif.Jumlah Daun (helai) dihitung jumlah daun sampel dari setiap sampel yang diamati. Pengamatan jumlah daun berakhir pada saat peralihan masa vegetatif ke masa generatif. Luas Daun per Tanaman (cm)diukur dengan menggunakan metode P x L x Konstata untuk semuah daun tanaman pada tanaman sampel. Pengamatan berakhir pada saat peralihan masa vegetatif ke generatif.Berat buah segar per tanaman (gram) buah Cabai ditimbang pada setiap kali melakukan pemanenan Cabai Besar.Diameter buah $(\mathrm{cm})$ diukur garis tengah dari buah Cabai, dengan menggunakan Jangka Sorong dan pengamatan pada saat panen. Jumlah buahdiamati dengan cara menghitung secara keseluruhan buah Cabai yang terdapat pada tanaman sampel.

Analisis Data

Data yang dikumpulkan diAnalisis secara statistik dengan menggunakan analisis Varian (Sidik ragam) sesuai dengan rancangan yang digunakan. Bila pengaruh Interaksi nyata terhadap Variabel yang diamati, maka dilanjutkan dengan uji jarak berganda Duncan 5\%. Bila pengaruh faktor tunggal yang nyata, maka dilanjutkan dengan uji BNT 5\% ( (Hanafiah, 1991)

\section{HASIL DAN PEMBAHASAN Tinggi Tanaman.}

Pengaruh tunggal Dosis Kirinyu dan varietas Cabai Besar tidak berpengaruh nyata terhadap tinggi tanaman untuk semua umur pengamatan (Grafik 1 dan 2).

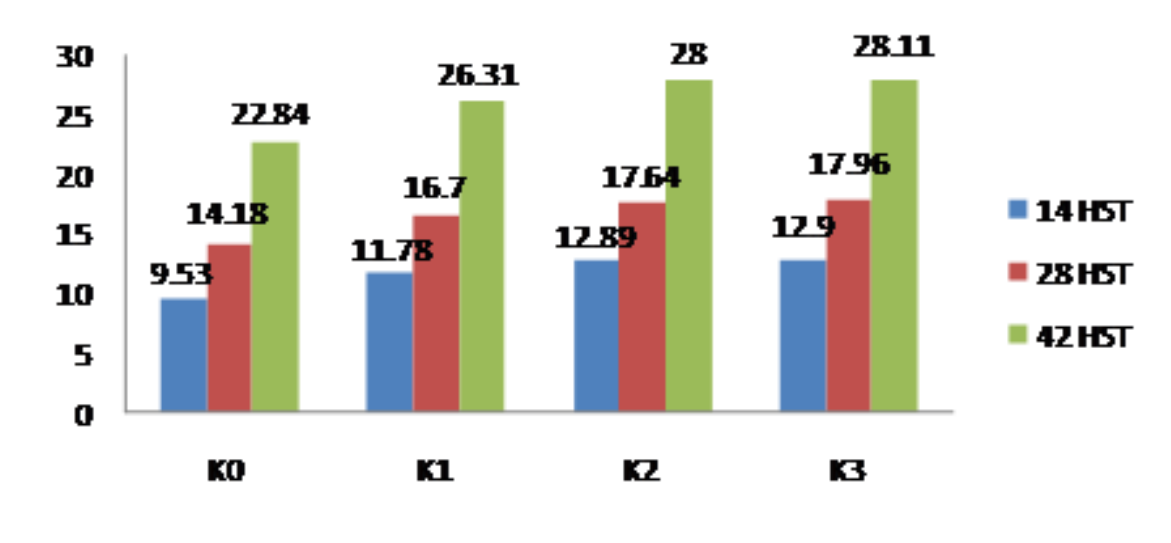

Grafik 1. Tinggi Tanaman Cabai Besar, Pengaruh Pemberian Dosis Kirinyu sebagai Sumber Bahan Organik terhadap Pertumbuhan dan Hasil Tanaman Cabai 


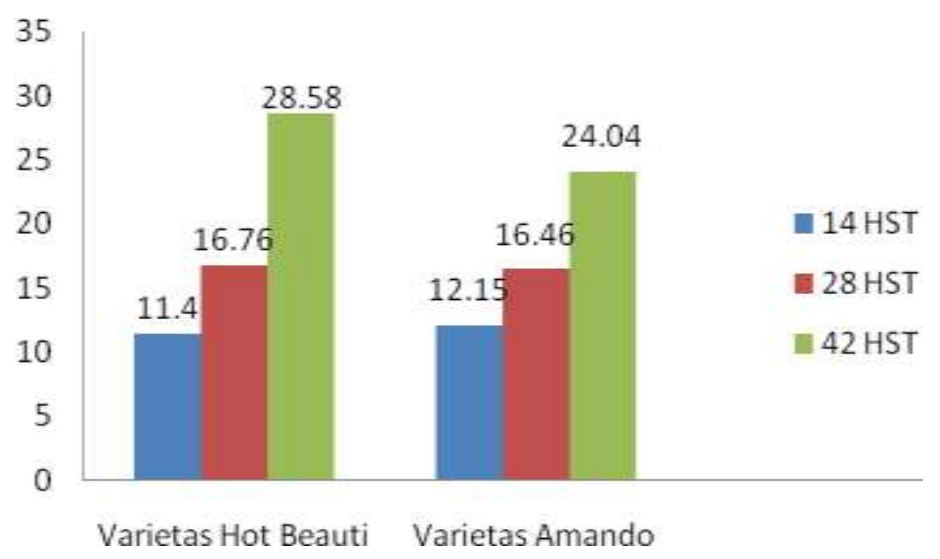

Grafik 2. Rerata Tinggi Tanaman Pengaruh Perlakuan Varietas Cabai Besar

Hal ini menunjukan bahwa tanaman dari hasil persilangan atau hibrida sangat membutuhkan unsur hara tanaman yang sudah secara siap untuk dimanfaatkan dalam proses pertumbuhan tanaman yang merupakan kebutuhan yang sangat mutlak, sedangkan pemberian bahan organik ke dalam tanah belum secara siap untuk langsung dimenfaatkan oleh tanaman, tetapi mesih melewati sebuah proses penting agar bahan organik dapat diserap oleh tanaman yakni bahan organik harus melewati proses dekomposisi, lamanya proses dekomposisi yang terjadi pada bahan organik yang diberikan akan berpengaruh terhadap pertumbuhan tanaman. Anonimus (2011) menegasakan jenis bahan organik yang diberikan ke tanah akan berpengaruh terhadap lamanya proses dekomposisi bahan organik, lamanya proses dekomposisi bahan organik membutuhkan waktu 2-4 bulan, makin banyak bahan organik yang diberikan pada tanah, waktu yang dibutuhkan untuk proses dekomposisi akan semakin banyak. Disamping itu juga peningkatan jumlah daun, dan luas daun tanaman terjadi pada pengamatan ke 42 hari setelah tanam (HST), sehingga proses fotosintesis yang akan menghasilkan unsur hara bagi tanaman dalam proses pertumbuhan tanaman termasuk tinggi tanaman secara sempurna baru akan terjadi setelah jumlah daun dan luas daun tanaman sudah tumbuh sampurna.

\section{Jumlah Daun}

Hasil

Analisis

Sidik

Ragammenunjukkan pengaruh tunggal dosis Kirinyu dan varietas Cabai Besar tidak berpengaruh nyata pada umur pengamatan 14 dan 28 hari setelah tanam, dan berbeda nyata pada pengamatan 42 hari setelah tanam. Perlakuan dosis 20 ton/ha memberikan jumlah daun paling banyak, sedangkan perlakuan varietas, Cabai Hot Beauty memberikan Jumlah Daun yang paling banyak (Tabel 4.2). 
Tabel. 4.2. Rerata Jumlah daun Cabai Besar Pengaruh Pemberian Dosis Kirinyu sebagai Sumber Bahan Organik terhadap Pertumbuhan dan Hasil Dua Varietas Cabai Besar pada berbagai umur pengamatan.

\begin{tabular}{cccc}
\hline \multirow{2}{*}{ Perlakuan } & \multicolumn{3}{c}{ Jumlah Daun Pada Berbagai Umur Pengamatan } \\
\cline { 2 - 4 } & 14 HST & 28 HST & 42 HST \\
\hline K0 & 6,72 & 8,34 & $15,72 \mathrm{a}$ \\
K1 & 6,50 & 8,89 & $17,39 \mathrm{ab}$ \\
K2 & 6,89 & 9,67 & $18,73 \mathrm{ab}$ \\
K3 & 7,11 & 10,11 & $19,23 \mathrm{~b}$ \\
\hline V1 & 6,72 & 9,33 & $21,67 \mathrm{~b}$ \\
V2 & 6,89 & 9,17 & $16,78 \mathrm{a}$ \\
\hline BNT 5\% & TN & TN & 2,29 \\
\hline
\end{tabular}

Keterangan: Angka-angka yang diikuti oleh huruf yang sama pada kolom yang sama berarti tidak berbeda nyata pada uji lanjut BNT dengan tingkat kepercayaan $95 \%$.

Tabel 4.2. Menunjukan pemberian bahan organik Kirinyu pada umur 42 hari setelah tanam dengan dosis 20 ton/ha memberikan jumlah daun terbanyak yaitu 19,23 helai. Hal ini menunjukan bahwa bahan organik Kirinyu yang ditambahkan ke dalam tanah dapat meningkatkan pertumbuhan tanaman. Keadaan ini terjadi karena bahan organik yang diberikan ke dalam tanah mengandung unsur hara, sehingga memberikan dampak yang positif terhadap pertumbuhan atau penambahan jumlah daun. Atmojo (2009) menjelaskan bahwa bahan organik yang ditambahkan ke dalam tanah dapat menambah ketersediaan bahan makanan (unsur hara) bagi tanaman yang dapat diserap tanaman dalam memenuhi kebutuhan hidup tanaman, pemberian bahan organik disamping berpengaruh terhadap pasokan hara tanah, juga tidak kalah pentingnya terhadap sifat fisik, biologis, dan sifat kimia tanah.Pemberian bahan organik kedalam tanah memberikan dampak yang baik terhadap tanah, tempat tumbuh tanaman. Tanaman akan memberikan respon yang positif apabila tempat tanaman tersebut tumbuh memberikan kondisi yang baik bagi pertumbuhan dan perkembangannya. Bahan organik yang ditambahkan kedalam tanah menyediakan zat pengatur tumbuh tanaman yang memberikan keuntungan bagi pertumbuhan tanaman, seperti vitamin, asam amino, auksin dan geberalin yang terbentuk melalui dekomposisi bahan organik (Karieeen, 2007).

Kirinyu (Chromolaena odorata) memiliki unsur hara makro N, P, K, dan unsur hara lainnya yang terdapat pada tanaman kirinyu. Unsur $\mathrm{N}$ merupakan nutrisi yang paling sering menjadi faktor pembatas pertumbuhan tanaman, unsur nitrogen diperlukan untuk pembentukan atau pertumbuhan bagian vegetatif tanaman seperti daun, batang, dan akar. Kandungan nitrogen berperan penting dalam hal pembentukan hijau daun, dan sangat berguna dalam proses fotosintesis, unsur $\mathrm{N}$ berperan untuk mempercepat fase vegetatif, karena fungsi utama unsur $\mathrm{N}$ itu sendiri sebagai sintesis klorofil (Acehpedia, 2010). Pada umur pengamatan 14 dan 28 hari setelah tanam (HST) memberikan pengaruh yang tidak nyata terhadap pertumbuhan jumlah daun tanaman cabai besar. Diduga dipengaruhi oleh bentuk bahan organik yang 
diaplikasikan ke dalam tanah, masih dalam bentuk segar yang belum siap untuk diserap oleh tanaman, tetapi harus melewati proses dekomposisi. proses dekomposisi bahan organik membutuhkan waktu 2-4 bulan, makin banyak bahan organik yang diberikan kepada tanah, waktu yang dibutuhkan untuk proses dekomposisi akan semakin banyak, dan untuk perlakuanutama varietas terjadi perbedaan yang nyata. Varietas V1(Hot Beauty) memiliki jumlah daun yang lebih banyak dibandingkan dengan varietas V2(Amando).Perbedaan sifat genetis pada tanaman akan berpengaruh terhadap pertumbuhan tanaman, berdasarkan data deskripsi varietas tanaman Cabai. Tanaman Cabai Hot Beauty merupakan varietas Cabai yang lebih toleran terhadap serangan penyakit dimusim hujan bila dibandingkan dengan varietas Amando, dengan ketahanan varietas tersebut sihingga daun tanaman tidak mudah gugur (Anonimus, 2011), daun tanaman
Anonimus (2011) mengemukakan jenis bahan organik yang diberikan akan berpengaruh dengan lamanya proses dekomposisi bahan organik, lamanya merupakan organ tanaman yang sangat penting dalam proses pertumbuhan tanaman yang mampu menghasilkan makanan bagi pertumbuhan tanaman, jumlah daun berkorelasi dengan luas daun pada tanaman yang berpengaruh terhadap proses fotosintesis.

\section{Luas Daun}

Hasil Analisis Sidik Ragam menunjukkan pengaruh tunggal dosis Kirinyu dan varietas Cabai Besar tidak berpengaruh nyata pada umur pengamatan 14 dan 28 hari setelah tanam, dan berbeda nyata pada pengamatan 42 hari setelah tanam, perlakuan dosis 20 ton/ha memberikan luas daun paling besar, sedangkan perlakuan varietas Cabai Amando memberikan luas daun yang paling paling besar (Tabel 4.3).

Tabel. 4.3.Rerata Luas Daun Cabai Besar $(\mathrm{Cm}) 2$ Pengaruh Pemberian Dosis Kirinyu sebagai Sumber Bahan Organik terhadap Pertumbuhan dan Hasil Dua Varietas Cabai Besar pada berbagai umur pengamatan

\begin{tabular}{lccc}
\hline \multirow{2}{*}{ Perlakuan } & \multicolumn{3}{c}{ Luas Daun $(\mathrm{cm})$ Pada Berbagai Umur Pengamatan } \\
\cline { 2 - 4 } & $14 \mathrm{HST}$ & $28 \mathrm{HST}$ & $42 \mathrm{HST}$ \\
\hline K0 & 41,46 & 60,44 & $121,75 \mathrm{a}$ \\
K1 & 45,28 & 84,12 & $155,88 \mathrm{~b}$ \\
K2 & 57,08 & 105,95 & $187,35 \mathrm{c}$ \\
K3 & 50,71 & 107,62 & $208,25 \mathrm{c}$ \\
\hline V1 & 40,15 & 67,88 & $149,60 \mathrm{a}$ \\
V2 & 57,12 & 11,19 & $187,02 \mathrm{~b}$ \\
\hline BNT 5\% & TN & TN & 30,35 \\
\hline
\end{tabular}

Keterangan: Angka-angka yang diikuti oleh huruf yang sama pada kolom yang sama berarti tidak berbeda nyata pada uji lanjut BNT dengan tingkat kepercayaan $95 \%$.

Tabel 4.3. menunjukan perlakuan utama Kirinyu sebagai sumber bahan organik dengan dosis 15 dan 20 ton/ha memberikan pengaruh yang tidak nyata terhadap luas daun tanaman Cabai untuk umur pengamatan 42 hari setelah tanam, tetapi berbeda nyata dengan perlakuan kontrol dan 5 
ton/ha. Hal ini menunjukkan bahwa bahan organik Kirinyu yang ditambahkan ke dalam tanah mengandung unsur hara yang dapat meningkatkan luas daun tanaman Cabai Besar. Anonimus (2010) mengemukakan bahwabahan organik yang diberikan ke dalam tanah dapat menambah bahan makanan (unsur hara) bagi tanaman yang dapat diserapnya dari dalam tanah.

Pemberian bahan organik kedalam tanah akan menambah unsur hara baik makro, maupun mikro yang dibutuhkan oleh tumbuhan (Anonimus, 2011), sehingga dengan ketersediaan akan unsur hara yang memadai bagi tanaman, maka proses fisiologis di dalam tubuh tanaman akan berlangsung secara sempurna, terutama unsur hara yang berperan dominan dalam pertumbuhan tanaman seperti unsur hara nitrogen (Anonimus, 2011). Kandungan unsur hara nitrogen merupakan unsur hara utama sebagai penyusun dari semua protein, yang merupakan penyusun protoplasma tanaman secara keseluruhan, dan diperlukan untuk pembentukan atau pertumbuhan bagian-bagian vegetatif, dan meningkatkan perkembangbiak mikro organisme didalam tanah (Winarso, 2003). Padaumur pengamatan 14 dan 28 hari setelah tanam memberikan pengaruh yang tidak nyata terhadap pertumbuhan luas daun, diduga bahan organik yang diberikan ke dalam tanah belum dapat dimanfaatkan tanaman dalam proses pertumbuhanya, dimana semuah bahan yang ditambahkan ke tanah harus melewati proses dekomposisi yang membutuhkan waktu yang lama. Anonimus (2009) mengemukakan lamanya proses dekomposisi bahan organik yang harus melewati tahap demi tahap, membutuhkan waktu yang relatif lama yaitu 2-4 bulan. Dan untuk perlakuan utama varietas terjadi perbedaan yang nyata. Varietas Amando (V2) memiliki luas daun yang lebih lebar dibandingkan dengan varietas Hot Beauty (V1). Dari hasil deskripsi varietas, Cabai Amando merupakan varietas Cabai yang ukuran daunnya lebih lebar bila dibandingkan dengan varietas Hot Beauty, luas daun tanaman Cabai varietas Amando dapat mencapai ukuran 12-14 cm dengan lebar berkisar 5-6 cm, namun pada varietas Hot Beauty ukuran daun hanya mencapai 8-13 cm, dengan lebar dapat mencapai 2,0-3,5 cm (Anonimus, 2006).

Daun tanaman adalah pembuat makanan yang utama bagi semua tumbuhan, untuk keperluan pertumbuhan tanaman. Tiap daun dipandang sebagai suatu pabrik makanan. Hadenomos (2011) menegaskan daun tanaman menangkap energi dari cahaya matahari serta karbon dioksida dari udara dan air dari tanah yang digunakan untuk membuat gula atau asimilat.

Jumlah Buah, Berat Buah, dan Diameter Buah

Hasil Analisis Sidik Ragam menunjukkan bahwa, pemberian bahan organik Kirinyu terhadap dua varietas Cabai Besar berpengaruh nyata terhadap Jumlah Buah, Berat Buah, dan Diameter Buah (Tabel 4.4). 
Tabel 4.4. Rerata Jumlah Buah, Berat Buah perTanaman, dan Diameter Buah Cabai Besar Pengaruh Pemberian Dosis Kirinyu sebagai Sumber Bahan Organik terhadap Pertumbuhan dan Hasil Dua Varietas Cabai Besar.

\begin{tabular}{ccccc}
\hline \multirow{2}{*}{ Perlakuan } & \multicolumn{4}{c}{ Produksi Cabai Besar } \\
\cline { 2 - 5 } & Jml Buah & B. Buah/Tan & D. Buah & B. Buah ton/ha \\
\hline K0 & $17,72 \mathrm{a}$ & $159,49 \mathrm{a}$ & $1,24 \mathrm{a}$ & 5,32 \\
K1 & $22,50 \mathrm{~b}$ & $220,50 \mathrm{~b}$ & $1,56 \mathrm{ab}$ & 7,35 \\
K2 & $29,05 \mathrm{c}$ & $261,45 \mathrm{c}$ & $1,58 \mathrm{~b}$ & 8,58 \\
K3 & $41,50 \mathrm{~d}$ & $373,50 \mathrm{~d}$ & $1,66 \mathrm{~b}$ & 12,46 \\
\hline V1 & $31,00 \mathrm{~b}$ & $279,00 \mathrm{~b}$ & $1,28 \mathrm{a}$ & 9,31 \\
V2 & $24,39 \mathrm{a}$ & $219,51 \mathrm{a}$ & $1,74 \mathrm{~b}$ & 7,32 \\
\hline BNT 5\% & 4,59 & 33,50 & 0,32 \\
\hline
\end{tabular}

Keterangan: Angka-angka yang diikuti oleh huruf yang sama pada kolom yang sama berarti tidak berbeda nyata pada uji lanjut BNT dengan tingkat kepercayaan $95 \%$.

Tabel 4.4. dapat dijelaskan perlakuan dosis bahan organic Kirinyu 20 ton/ha menujukan perbedaan yang nyata dengan perlakuan kontrol, 10 ton/ha, dan 15 ton/ha dengan hasil jumlah buah terbanyak (41,50 buah). Hal ini menunjukan bahwa unsur hara yang terdapat di dalam bahan organik Kirinyu yang diberikan pada tanah untuk pertumbuhan tanaman Cabai besar berpengaruh terhadap banyaknya buah Cabai. Atmojo (2009) mengemukakan bahwa bahan organic Kirinyu memiliki kandungan unsur hara yang lengkap dan sangat penting dalam proses pertumbuhan serta hasil dari tanaman. Kandungan hara dalam Kirinyu (Chromolaenaodorata) sangat lengkap diantara kandungan fosfor $(\mathrm{P})$, kandungan ini diperlukan tanaman untuk membawa energy dalam pembentukan hasil tanaman.Unsur $P$ dibutuhkan tanaman untuk pembentukan karbohidrat, maka unsur $\mathrm{P}$ dibutuhkan dalam jumlah besar pada pembungaan, waktu pertumbuhan benih, pemasakan buah dan biji.Penambahan unsur $\mathrm{P}$ yang terdapat dalam bahan organik dari Kirinyu secara langsung berpengaruh terhadap Jumlah Buah.

Peningkatan Jumlah Buah yang disebabkan perlakuan bahan organik yang diberikan adalah respon nyata yang berkaitan dengan banyaknya jumlah bahan organik yang ditambahkan kedalam tanah sudah terdekomposisi dan sudah dimanfaatkan tanaman secara sempurna. Dari tabel $4.4 \mathrm{di}$ atas menunjukan perlakuan dosis 20 ton/ha mempunyai jumlah buah yang paling banyak, perbedaan dosis bahan organik yang ditambahkan kedalam tanah, berkorelasi positif terhadap jumlah unsur hara yang dihasilkan dari bahan organik yang ditambahkan kedalam tanah, karena pada waktu umur tanaman mulai dapat dipanen proses dekomposisi bahan organik yang diberikan kedalam tanah sudah terdekomposis secara normal, sehingga hasil proses dekomposisi sudah dapat dimanfaatkan oleh tanaman, akibatnya akan berpengaruh nyata untuk pertumbuhan dan hasil dari tanaman, dengan demikian produksi tanaman akan meningkat, kerena bahan organic dengan dosis 20 ton/ha dapat 
memberikan tambahan unsur hara yang lebih banyak. Dan perlakuan utama varietas terjadi perbedaan yang nyata. Varietas Hot Beauty (V1) memiliki jumlah buah yang lebih tinggi dibandingkan dengan varietas Amando (V2). Hal ini diduga dipengaruhi sifat genetis yang berada pada masingmasing varietas, diantaranya ketahanan varietas tertentu terhadap curah hujang yang tinggi. Prajananta (2011) menyatakan varietas Cabai Hot Beauty dikenal sebagai vaietas Cabai Besar yang lebih toleran terhadap serangan penyakit yang disebabkan oleh intensitas hujan yang tinggi bila dibandingkan dengan varietas lainnya termasuk dengan varietas Amando, varietas Amando tidak tahan terhadap curah hujan secara terus menerus. Penelitian ini dilakukan pada bulan November yang curah hujan masih sering terjadi sehingga bunga Cabai tidak terjadi pembuahan dan menyebabkan bunga Cabai gugur.

Berdasarkan tabel 4.4. Maka dapat dijelaskan perlakuan utama dosis bahan organik Kirinyu 20 ton/ha menujukan perbedaan yang nyata dengan perlakuan kontrol, 10 ton/ha, dan 15 ton/ha dengan hasil Berat Buah terbanyak $(373,50$ g). Hal ini menunjukan bahwa semakin banyak dosis Kirinyu yang diberikan ke dalam tanah sebagai sumber bahan organik untuk tanaman Cabai dapat memberikan pengaruh baik terhadap Berat Buah Cabai yakni dapat meningkatkan pertambahan Berat Buah (12,46 ton/ha), hal ini karena Kirinyu yang diberikan sebagai sumber bahan organik mengandung unsur hara yang dapat meningkatkan pertumbuhan tanaman, diantaranya unsur hara $\mathrm{N}, \mathrm{P}$, dan $\mathrm{K}$ (Winarso, 2003).

Frare(2007), mengemukakan perbedaan dosis pemberian bahan organik yang ditambahkan kedalam tanah akan berpengaruh terhadap ketersediaan unsur hara yang dapat dimanfaatkan tanaman dalam proses pertumbuhan. Makin banyak dosis bahan organik dari tanaman Kirinyu yang diberikan pada tanah akan berpengaruh terhadap ketersediaan unsur hara dalam tanah yang akan dipergunakan tanaman sebagai sumber bahan makanan dalam proses pertumbuhan dan produksi tanaman. Tanaman Kirinyu merupakan bahan pupuk hijau yang sangat berpengaruh terhadap ketersediaan bahan organik, hal ini terjadi karena komposisi kandungan unsur hara dalam jaringan Kirinyu cukup besar dan lengkap, sehingga akan berpengaruh terhadap jumlah unsur hara yang dihasilkan dari masing-masing peningkatan dosis Kirinyu sebagai sumber bahan organik.

Perlakuan utama varietas terjadi perbedaan yang nyata. varietas Hot Beauty (V1) memiliki berat buah yang lebih tinggi dibandingkan dengan varietas Amando (V2). Hal ini diduga karena keterbatasan genetis dari varietas tanaman masing-masing, dan juga lingkungan tumbuh tanaman yang kurang mendukung dimana intensitas hujan yang sangat tinggi, sehingga banyak bakal buah yang gugur karena sifat genitis tanaman Cabai tidak tahan terhadap intensitas hujan yang terlalu tinggi (Anonimus, 2006 ). Ketahanan varietas Hot Beauty terhadap curah hujang yang tinggi menyebapkan Jumlah Buah Cabai yang dihasilkan lebih banyak dari varietas sehingga akan berpengaruh terhadap Berat Buah.

\section{Diameter Buah}

Tabel 4.4. dapat dijelaskan perlakuan dosis bahan organik kirinyu 10, 15, dan 20 ton/ha memberikan pengaruh yang tidak nyata terhadap diameter buah, tetapi berbeda nyata dengan perlakuan kontrol. Ini diduga 
terdapat keterbatasan sifat genetis dan benih yang digunakan merupakan benih hibrida yang sangat bergantung terhadap input luar khususnya bahan anorganik. Pemberian bahan organik juga memberikan pengaruh terhadap diameter buah sekalipun tidak menyamai pemberian bahan anorganik, ini menunjukan bahan organik Kirinyu mengandung unsur hara yang dapat meningkatkan pertumbuhan dan produksi dari tanaman Cabai Besar, karena unsur hara yang digunakan untuk proses metabolisme dalam tubuh tanaman tersedia. Adanya pengaruh baik dari pemberian bahan organik yang dipengaruhi oleh kandungan unsur $\mathrm{K}$ yang terdapat dalam kandungan bahan organik dari Kirinyu diberikan. Berdasarkan hasil analisis bahan organik Kirinyu terdapat $0,99 \%$ unsur $\mathrm{K}$. Unsur $\mathrm{K}$ ini berfungsi untuk peningkatan kualitas buah, sangat membantu pembentukan protein, karbohidrat dan gula, selain itu juga kandungan unsur hara $\mathrm{K}$ berperan penting dalam membantu pengangkutan gula dari daun ke buah, sehingga akan berpegaruh terhadap pertumbuhan biji atau buah pada tanaman (Acehpedia, 2010). Dan untuk varietas terjadi perbedaan yang nyata. Varietas Amando (V2) memiliki diameter buah lebih tinggi dibandingkan dengan varietas Hot Beauty (V1). Berdasarkan data dari hasil penelitian, diskripsi Cabai Besar untuk varietas Amando (V2) memiliki diameter lebih besar dari pada varietas Hot Beauty (V1). Diameter Cabai varietas Amando dapat mencapai $2,2 \mathrm{~cm}$, sedangkan untuk varietas Hot Biauty hanya berkisar 1,2

DAFTAR PUSTAKA

Acehpedia. 2010. Fungsi Unsur Hara. http://acehpedia.org/FungsiUn sur Hara. Tanggal 10 September 2011 cm (Anonimus, 2006), dengan demikian akan berpengaruh terhadap diameter buah, sehingga diperkirakan selain dipengaruh dari perlakuan dosis bahan organik yang diberikan juga keunggulan dari masing masing varietas.

\section{SIMPULAN}

1. Tidak terjadi interaksi kombinasi perlakuan bahan organik Kirinyu dengan varietas Cabai Besar terhadap pertumbuhan dan hasil Cabai Besar.Penggunaan dosis Kirinyu (Chrolaena odorata) 20 ton/ha memberikan pertumbuhan terbaik pada pengamatan 42 hari setelah tanam (HST) terhadap Variabel pertumbuhan yaitu Jumlah $\operatorname{Daun}(19,23$ helai)dan Luas Daun (208,25 cm), sedangkan pada variabel Produksi yaitu Jumlah Buah (41,50 buah), Berat Buah (373,50 gram), dan Diameter Buah $(1,66 \mathrm{~cm})$.

2. Varietas Hot Beauty memperlihatkan hasil yang lebih baik dibandingkan varietas Amando diantaranya Jumlah Daun (21,67 helai), Jumlah Buah yang lebih banyak $(31,00$ buah), dan Berat Buah $(279,00$ gram).

\section{UCAPAN TERIMA KASIH}

Pada kesempatan ini penulis ingin mengucapkan terima kasih kepada semua pihak yang telah membantu dengan caranya masing-masing dalam melengkapi tulisan ini.

Anonimus. 2006. Deskripsi Cabai Besar Varietas Hibrida. http://www.deptan.go.id/bdd/a dmin/file/SK-163-06.pdf. Tanggal 29 Agustus 2011 
Anonimus. 2010. Proses Dekomposisi

Bahan Organik. http://webcache.

googleusercontent. /search?q= cache:P8YFOJZFbCMJ:id-id.

facebook.

com/topic.php\%3Fuid

\%3D176580962380783\%26

topic\%3D551+lamanya+deko

mposisi+bahan+organik\&cd $=4$

$\& \mathrm{hl}=\mathrm{id} \& \mathrm{ct}=\mathrm{clnk} \& \mathrm{gl}=\mathrm{id} \& \mathrm{clien}$

$\mathrm{t}=$ firefox-

a\&source $=w w w \cdot g o o g l e . c o . i d$.

Tanggal 29 Agustus 2011

Anonimus. 2011. Memilih Varietas

Cabai yang tahan diMusin

Hujan.

http//artikelterbaru.com/pertan

ian/memilih-lokasi-

penanaman-cabai-dan-

memilih-varietas-yang-tahan-

di-musim-hujan-

2011591.html. Tanggal 29

Agustus 2011

Atmojo, Suntoro. 2009. Peranan Bahan

Organik

Terhadap

Kesuburan Tanah Dan

Upaya

Pengelolaannya.http://suntor o.staff.uns.ac.id/files/2009/0

4/ pengukuhan-prof-

suntoro.pdf. Tanggal 29

Agustus 2011

Frare, A. P.F. 2007. Pengaruh

Kombinasi Pupuk Hijau

Biomasa Kirinyu

(Choromolaena odorata)

Dengan Dosis Pemupukan

Anorganik N, P, K Terhadap

Komponen Pertumbuhan dan

Hasil Tanaman Jagung.

Skripsi Pada fakultas

Pertanian Universitas Nusa

Cendana.

Hanafiah. 2008. Rancanagan Percobaan

Teori dan Aplikasi. PT Rajagrafindo Persada. Jakerta
Karieeen. 2007. Pengaruh Bahan

Organik Terhadap Produksi

Tanaman.

http://karieeen.wordpress.co

m/2007/06/18/bahan-

organik/. Tanggal 29

Agustus 2011

Prajananta, Final.1995. Budidaya

Tanaman Cabai. Penebar

Swadaya. Jakarta 2010. 38 Kiat Sukses

Bertanam Cabai di Musim

Hujan. Penebar Swadaya.

Jakarta

Setiadi. 1995. Bertanam Cabai. Penebar Swadaya, Anggota IKAPI. Jakarta.

Wanarso, S. 2003. Kesuburan Tanah

Dasar Kesehatan dan Kualitas Tanah. Gova Media. Jember 